\title{
Hukum Adat Masyarakat Petapahan dalam Pengelolaan Lingkungan Sebagai Upaya Pemenuhan Hak Masyarakat Adat
}

\author{
Hengki Firmanda S \\ Fakultas Hukum Universitas Riau \\ E-mail: hengki.firmanda@gmail.com
}

\begin{abstract}
Indigenous peoples have always made the environment as a dependent on meeting all their needs. Natural resources are managed in accordance with local tradition in customary law. The tradition originated from living habits amongst the people. Such habits are followed continuously, thus forming customary law. Petapahan Kampar community also has a customary law in environmental management that see the environment as a good partner. The method used is the juridical sociological method. The research location is the Petapahan village Tapung District of Kampar Regency of Riau Province. The data collection technique used is observation, interviews, questionnaires and review of the literature. The results of this study are of Petapahan customary law in environmental management consists of managing waters and land area. The marine area or river used to look for the results of the activities of the river is fish manubo using traditional tools and the sap of the rubber tree roots are used to make fish become dizzy so easy to catch. Landfall their customary forests, known as the Utan Imbo Putuih, who managed to become a permanent nature until today. The efforts made by people to obtain their rights is to manage simultaneously both the waters and land area so that the entire community benefit from these natural products.
\end{abstract}

Keywords: Customary Law, Environmental Management, Petapahan Community 


\begin{abstract}
Abstrak
Masyarakat adat selalu menjadikan lingkungan sebagai tempat bergantung untuk memenuhi segala kebutuhan hidupnya. Sumber daya alam dikelola sesuai dengan tradisi yang berkembang di daerah hukum adat tersebut. Tradisi tersebut berawal dari kebiasaan-kebiasaan yang hidup ditengah-tengah masyarakat. Kebiasaan tersebut diikuti secara terus menerus, sehingga membentuk hukum adat. Masyarakat Petapahan Kampar juga mempunyai hukum adat dalam pengelolaan lingkungan yang melihat lingkungan sebagai mitra yang baik. Metode yang digunakan adalah metode sosiologis yuridis. Lokasi penelitian adalah Desa Petapahan Kecamatan Tapung Kabupaten Kampar Provinsi Riau. Teknik pengumpulan data yang digunakan ialah observasi, wawancara, kuisioner dan kajian kepustakaan. Hasil penelitian ini ialah hukum adat masyarakat Petapahan dalam pengelolaan lingkungan terdiri dari pengelolaan kawasan perairan dan kawasan darat. Kawasan perairan atau sungai digunakan untuk kegiatan mencari hasil-hasil sungai, salah satunya manubo ikan dengan menggunakan alat-alat tradisional dan getah akar pohon karet yang berfungsi untuk membuat ikan menjadi pusing sehingga mudah untuk ditangkap. Kawasan daratan adanya hutan adat yang dikenal dengan sebutan Utan Imbo Putuih, yang dikelola agar menjadi tetap alami hingga saat ini. Upaya yang dilakukan oleh masyarakat untuk memperoleh haknya adalah dengan melakukan pengelolaan secara bersama-sama baik itu kawasan perairan dan kawasan daratan, sehingga seluruh masyarakat memperoleh manfaat dari hasil-hasil alam tersebut.
\end{abstract}

Kata Kunci: Hukum adat, Pengelolaan Lingkungan, Masyarakat Petapahan

\title{
A. Pendahuluan
}

\section{Latar Belakang}

Keberadaan manusia dan lingkungan tidak dapat dipisahkan, terdapat hubungan mutualisme yang mengharuskan kepada setiap manusia untuk dapat 
menjaga/melindungi dan mengelola lingkungan secara baik. Pengelolaan lingkungan hidup adalah upaya terpadu untuk melestarikan fungsi lingkungan hidup yang meliputi kebijaksanaan penataan, pemanfaatan, pengembangan, pemeliharaan, pemulihan, pengawasan, dan pengendalian lingkungan hidup.

Sumber Daya Alam (SDA) seperti air, udara, tanah, hutan dan lainnya merupakan sumberdaya yang penting bagi kelangsungan hidup makhluk hidup termasuk manusia. Bahkan, SDA ini tidak hanya mencukupi kebutuhan hidup manusia, tetapi juga dapat memberikan kontribusi besar terhadap kesejahteraan manusia itu sendiri. Hanya saja, semua itu membutuhkan pengelolaan SDA yang baik dan tidak berdampak buruk sehingga tidak menimbulkan kerugian di masa yang akan datang.

Intergenerational Equity merupakan suatu gagasan bahwa generasi sekarang menguasai SDA yang ada di bumi sebagai titipan (in trust) untuk dipergunakan generasi yang akan datang. Setiap generasi merupakan penjaga (trustee/custodian) dari planet bumi ini untuk kemanfaatan generasi berikutnya, dan sekaligus sebagai penerima manfaat (beneficiaries) dari generasi sebelumnya. Keadaan demikian menuntut tanggung jawab dari generasi sekarang untuk memelihara peninggalan (warisan) seperti halnya kita menikmati berbagai hak untuk menggunakan warisan bumi ini dari generasi sebelumnya. ${ }^{1}$

Secara yuridis, negara Indonesia sudah memiliki beberapa regulasi yang berkaitan dengan lingkungan. Salah satu bentuk regulasi tersebut terdapat pada pasal $28 \mathrm{H}$ ayat (1) Undang-Undang Dasar 1945 yang menuliskan bahwa: "Setiap orang berhak hidup sejahtera lahir dan bathin,

1 Mas Achmad Santoso, Good Governance Hukum Lingkungan, Penerbit ICEL (Indonedian Center For Environmental Law), Jakarta: 2001, hlm. 163. 
bertempat tinggal, dan mendapatkan lingkungan hidup yang baik dan sehat serta berhak memperoleh pelayanan kesehatan". Hal ini menegaskan kepada kita bahwa negara harus menjamin dan menghormati hak setiap warga negara untuk mendapatkan lingkungan hidup yang baik dan sehat. Hal-hal yang bertentangan dengan itu, dianggap sebagai perbuatan yang inskonstitusional.

Secara geografis, posisi negara Indonesia berada pada dua benua dan dua samudera, selain itu berada pada lintasan garis khatulistiwa. Terhadap posisi tersebut, Indonesia dikenal sebagai negara agraris dan negara maritim. Keberadaan negara Indonesia yang terdiri dari beberapa pulau juga berdampak terhadap keberagaman bangsa, suku, ras dan agama. Pada tiap suku, adat dan budaya memiliki aturan-aturan sendiri yang merupakan warisan para leluhurnya. Secara konstitusi, masyarakat adat dan hukum adat diakui keberadaannya.

Pengakuan tersebut tertulis dalam Pasal 18B ayat (2) yang menuliskan bahwa: "Negara mengakui dan menghormati kesatuan-kesatuan masyarakat hukum adat beserta hak-hak tradisionalnya sepanjang masih hidup dan sesuai dengan perkembangan masyarakat dan prinsip Negara Kesatuan Republik Indonesia, yang diatur dalam Undang-Undang”. Aturan inilah yang menjadi dasar perlindungan masyarakat adat beserta hak-hak tradisionalnya.

Keberadaan masyarakat adat Petapahan, Tapung Hilir, Kabupaten Kampar Provinsi Riau juga memiliki kegiatan dan aturan adat dalam lingkungan masyarakat adatnya. Setiap aktifitas masyarakat adat Petapahan tentunya tidak dapat dipisahkan dari lingkungan. Komunitas masyarakat yang didominasi oleh suku Domo Melayu ini memiliki beberapa ritual adat dalam menjaga lingkungan adatnya.

Desa Petapahan terletak di pinggir sungai Tapung kiri dan dikelilingi oleh sungai kecil yaitu Sungai Petapahan. Desa Petapahan ini berada dipertengahan sepanjang aliran 
sungai Tapung kiri yang bermuara di sungai Jantan (sungai siak). Sungai jantan ini menurut orang Tapung dahulunya bernama sungai Tapung, sesuai dengan sungai-sungai yang berdekatan dengannya, yaitu disebelah Utara ada sungai Rokan Kiri dan Rokan Kanan yang bertemu dan dari situ sampai kemuaranya bernama sungai Rokan, dan disebelah selatan ada sungai Kampar Kanan dan Kampar Kiri dan bertemu di muara Sako dan dari muara Sako sampai ke muaranya bernama sungai Kampar. ${ }^{2}$

Desa Petapahan yang berada dekat dengan kawasan perairan, memiliki kegiatan ritual adat dalam menjaga lingkungan adatnya seperti sungai adat dan hutan adat. Ritual adat ini merupakan warisan dari para leluhurnya untuk tetap terus dipertahankan oleh anak cucunya, dipercayakan bahwa setiap ritual adat memiliki sanksi adat. Sehingga ritual adat ini tidak dapat diganggu gugat oleh negara, karena keberadaannya sudah ada sebelum negara ini ada. Ritualritual adat yang dilakukan dalam penjagaan terhadap lingkungan, dilakukan oleh masyarakat adat Petapahan adalah sebagai bentuk ucapan terimakasih dan kesyukuran atas pemberian-pemberian Tuhan dengan perantara lingkungan, seperti hutan dan sungai. Ritual adat ini jugalah yang menjadi hukum adat masyarakat Petapahan dalam pengelolaan dan pemanfaatan lingkungan.

\section{Rumusan Masalah}

Persoalan pengelolaan dan perlindungan lingkungan di Indonesia masih membutuhkan upaya-upaya perbaikan. Terhadap upaya tersebut, salah satunya dilakukan dengan tetap menjaga eksistensi hukum adat di Indonesia. Salah satu komunitas adat di Kabupaten Kampar Provinsi Riau, yang masih terjaga dan diwarisi secara turun temurun adalah

${ }^{2}$ Hasyim Arsyad, Sejarah Bekas Kerajaan Petapahan, Pekanbaru, 1986, hlm. 1. 
masyarakat adat Petapahan. Sebagaimana keberadaan masyarakat ini tidak luput dari aturan-aturan atau nilai-nilai adat istiadat yang merupakan hasil kesepakatan bersama. Fokus penelitian ini dilakukan terhadap hukum adat masyarakat Petapahan dalam pengelolaan lingkungan sebagai upaya pemenuhan hak masyarakat adat.

\section{Metode Penelitian}

\section{a. Jenis Penelitian}

Jenis penelitian yang akan laksanakan adalah penelitian sosiologis yuridis, yaitu penelitian yang dilakukan dengan cara mengadakan identifikasi hukum dan bagaimana efektifitas pelaksanaan hukum itu berlaku di masyarakat. ${ }^{3}$ Penelitian ini akan melihat fakta di lapangan berdasarkan peraturan perundangundangan yang berkaitan dengan hukum adat masyarakat Petapahan dalam pengelolaan lingkungan sebagai upaya pemenuhan hak masyarakat adat.

\section{b. Lokasi Penelitian}

Lokasi penelitian adalah Desa Petapahan Kecamatan Tapung Kabupaten Kampar Provinsi Riau.

\section{c. Responden}

1) Tokoh Masyarakat Adat Petapahan;

2) Camat Tapung;

3) Masyarakat adat Petapahan

\section{d. Sumber Data}

Data yang digunakan dalam penelitian ini adalah:

1) Data primer adalah data yang diperoleh secara langsung dari responden dengan menggunakan alat pengumpulan data berupa wawancara dan kuisioner;

3 Soejono Soekanto, Pengantar Penelitian Hukum, Ui-Press, Jakarta, 2006, hlm.76. 
2) Data sekunder adalah data yang diperoleh dari peraturan perundang-undangan dan literatur-literatur yang berhubungan dengan masalah pokok dari penelitian ini.

3) Data tersier adalah data yang diperoleh melalui kamus, ensiklopedi dan sebagainya yang berfungsi untuk mendukung data primer dan sekunder.

\section{e. Teknik Pengumpulan Data}

Adapun teknik pengumpulan data yang peneliti gunakan sebagai berikut:

1) Observasi

Yaitu pengumpulan data yang dibutuhkan dalam penelitian ini dengan cara pengamatan langsung terhadap objek penelitian yaitu hukum adat masyarakat Petapahan dalam pengelolaan lingkungan sebagai upaya pemenuhan hak masyarakat adat.

2) Wawancara

Yaitu mengadakan proses tanya jawab langsung kepada responden dengan pertanyaan-pertanyaan non struktur terkait permasalahan.

3) Kuisioner

4) Yaitu alat pengumpul data berupa daftar pertanyaan yang telah peneliti sebarkan atau peneliti berikan kepada responden, kemudian peneliti kumpulkan kembali untuk diolah.

5) Kajian Kepustakaan Yaitu untuk memperlengkap data yang dibutuhkan dalam penelitian ini, peneliti melakukan pengumpulan data dengan literatur kepustakaan yang mempunyai hubungan logis dengan permasalahan yang sedang diteliti. Hal ini dilakukan untuk mencari data sekunder sebagai pendukung terhadap data primer. 


\section{B. Kajian Teoritik}

\section{Hukum Adat}

Hukum adat merupakan hukum asli bangsa Indonesia yang pada umumnya berbentuk tidak tertulis. Hukum adat tumbuh dan berkembang serta tetap dipertahankan oleh masyarakat adat, dan berpangkal dari kehendak nenek moyang. Soepomo mengatakan bahwa hukum adat itu berurat akar dalam kebudayaan tradisional, sesuai dengan fitrahnya sendiri, terus menerus dalam keadaan tumbuh dan berkembang seperti hidup itu sendiri. ${ }^{4}$

Bentuk hukum adat yang cenderung tidak tertulis, maka hukum adat memiliki kemampuan menyesuaikan diri dan fleksibel, mengikuti perkembangan masyarakat adat. Menurut Van Dijk, hukum adat mempunyai beberapa corak, yakni mengandung sifat yang sangat tradisional karena berpangkal pada kehendak nenek moyang, hukum adat dapat berubah, tidak statis melainkan dinamis, dan bersifat elastis yakni sanggup menyesuaikan diri. $^{5}$ Sifat elastis hukum adat dikarenakan bentuknya yang tidak tertulis, sehingga hukum adat mampu mengadaptasi dengan kejadian dan keadaan sosial, dimana ia mudah berubah untuk menyesuaikan dengan perkembangan situasi sosial.

Pengertian hukum adat lebih sering diidentikkan dengan kebiasaan atau kebudayaan masyarakat setempat di suatu daerah. Hukum adat adalah aturan kebiasaan manusia dalam hidup bermasyarakat, yang pada intinya bermula dari nilainilai yang tumbuh, berkembang dan diterima oleh masyarakat. Istilah hukum adat berasal dari bahasa Belanda, yaitu dari Adatrecht. Istilah adatrech secara resmi mulai dikenal, yakni diatur dalam Undang-Undang Belanda, Stbl.

${ }^{4}$ Achmad Sodiki, Politik Hukum Agraria, Konstitusi Pers, Jakarta, 2013, hlm. 14.

5 Komar Andasasmita, Notaris Selayang Pandang, Alumni, Bandung, 1983, hlm. 5. 
1929 Nomor 221 Jo Nomor 487 yang mulai berlaku sejak tanggal 1 Januari $1929 .^{6}$

Hukum adat bisa diartikan sebagai wujud gagasan kebudayaan yang terdiri atas nilai-nilai budaya, norma, hukum, dan aturan-aturan yang satu dengan lainnya berkaitan menjadi suatu sistem dan memiliki sanksi. Menurut Kamus Besar Bahasa Indonesia, adat adalah aturan (perbuatan) yang lazim diturut atau dilakukan sejak dahulu kala; cara (kelakuan) yang sudah menjadi kebiasaan; wujud gagasan kebudayaan yang terdiri atas nilai-nilai budaya, norma, hukum, dan aturan yang satu dengan lainnya berkaitan menjadi budaya, norma, hukum, dan aturan yang satu dengan lainnya berkaitan menjadi suatu sistem. Karena istilah adat yang telah diserap kedalam bahasa Indonesia menjadi kebiasaan, maka istilah hukum adat dapat disamakan dengan hukum kebiasaan.

Pada umumnya adat memiliki ciri khas sebagai berikut:

a. Keagamaan (magic religious)

Adat menghendaki agar setiap manusia percaya dan taqwa kepada Tuhan Yang Maha Esa dengan mengakui segala sesuatu terjadi karena berkat dan rahmat Tuhan, dan yang ada di muka bumi tidak ada yang kekal abadi. Oleh karena itu hukum adat selalu menghendaki agar setiap perbuatan mendapat ridho dari Tuhan dan diajuhkan dari segala ancaman kemarahan Tuhan.

\section{b. Kebersamaan (comunal)}

Sifat kebersamaan dalam hukum adat ini mengandung arti bahwa manusia menurut hukum adat merupakan makhluk dalam ikatan kemasyarakatan yang erat. Seluruh lapisan makhluk diliputi oleh rasa kebersamaan anggota baik sesama keluarga, kerabat, tetangga yang didasarkan pada tolong

6 A. G. Kertasapoetra Setiadi, Hukum Tanah, jaminan UndangUndang Pokok Agraria bagi Keberhasilan Pendayagunaan Tanah, Bina Aksara, Jakarta, 1985, hlm 4. 
menolong dan saling membantu satu sama lain. Sifat-sifat kebersamaan dapat dilihat dari kenyataan sehari-hari, seperti hukum kampung, tukun tetangga atau rukun warga, dimana jika ada yang sakit atau meninggal dunia maka berduyunduyunlah para tetangga mendatangi sanak saudara untuk turut serta berduka cita.

c. Serba kongkrit

Mengandung hubungan-hubungan hukum yang dilakukan tidak samar-samar antara kata dan perbuatan berjalan serasi, jelas dan nyata. Misalnya dalam perjanjian jual beli, perjanjian baru terjadi jika jelas dan nyata pembeli telah membayar harganya dan penjual telah menyerahkan barang yang telah dijualnya.

d. Sangat Visual

Hukum adat bercorak sangat visual mengandung arti hubungan-hubungan hukum itu dianggap terjadi jika sudah ada tanda ikatan yang nampak, jika belum ada tanda-tanda maka hubungan itu baru merupakan omong kosong saja, baru sekedar menyampaikan keinginan atas menaruh perhatian.

e. Tidak dikodifikasi

Hal ini mengandung arti tidak dihimpun dalam suatu atau beberapa kitab undang-undang menurut sistem tertentu, sebagaimana halnya dengan hukum yang berasal dari Eropa. Hal ini tidak berarti bahwa tidak ada hukum adat yang tertulis dan dibuat menjadi buku, namun tidak sedikit hukum adat yang tidak pernah dicatat, dibukukan menurut cara setempat.

f. Tradisional

Mengandung arti turun temurun sejak dahulu hingga sekarang tetap dipertahankan dan dihormati, misalnya orang Minangkabau tetap mempertahankan Datuk Parpatihman Sebatan. Hukum adat yang tradisional ini disesuaikan dengan tradisi kepercayaan alam, yang besar pengaruhnya terhadap alam fikiran masyarakat. 
g. Dapat berubah dan mampu menyesuaikan diri

Perubahan hukum dilakukan tidak dengan cara melengkapi atau menghilangkan ketentuan yang ada, tetapi membiarkan saja membuat ketentuan-ketentuan yang baru. Hal ini juga menggambarkan bahwa adat mudah dan mampu menyesuaikan dengan keadaan yang baru. Kemampuan menyesuaikan diri ini bukan saja dikarenakan sifat hukum yang tidak tertulis dan tidak dikualifikasi melainkan karena sifat keterbukaannya.

\section{Masyarakat Adat}

Masyarakat adat merupakan kesatuan manusia yang teratur, menetap di suatu daerah tertentu, mempunyai penguasa-penguasa, dan mempunyai kekayaan yang berwujud maupun tidak berwujud. Bushar Muhammad memberikan pengertian masyarakat hukum adat, yakni masyarakat hukum yang anggota-anggotanya merasa terikat dalam suatu ketertiban berdasarkan kepercayaan, bahwa mereka semua berasal dari satu keturunan yang sama ataupun berasal dari satu tanah tempat bermukim yang sama.

Hazairin memberikan pengertian masyarakat hukum adat, yakni kesatuan kemasyarakatan yang mempunyai kelengkapan untuk sanggup berdiri sendiri, yaitu mempunyai kesatuan hukum, kesatuan penguasa, dan kesatuan lingkungan hidup berdasarkan hak bersama atas tanah dan air bagi semua anggotanya. Sementara itu, Saragih menyebutnya dengan istilah persekutuan hukum, yakni sekelompok orangorang yang terikat sebagai satu kesatuan dalam suatu susunan yang teratur yang bersifat abadi, dan memiliki pimpinan serta kekayaan baik berwujud maupun tidak berwujud dan mendiami atau hidup di atas suatu wilayah tertentu.

Secara yuridis formil, pengertian masyarakat hukum adat tercantum dalam Peraturan Menteri Negara Agraria/Kepala Pertanahan Nasional Nomor 5 Tahun 1999 tentang Pedoman Penyelesaian Masalah Hak Ulayat Masyarakat Hukum Adat, 
Pasal 1 angka 3, yakni sekelompok orang yang terikat oleh tatanan hukum adatnya sebagai warga bersama suatu persekutuan hukum karena kesamaan tempat tinggal ataupun atas dasar keturunan.

Unsur-unsur yang menjadi ciri dari masyarakat hukum adat, yaitu:

a. Kelompok manusia yang teratur dan terikat oleh kesamaan keturunan (genealogis) atau kesamaan wilayah (teritorial);

b. Menetap di wilayah/daerah tertentu (mempunyai wilayah);

c. Mempunyai aturan hidup bersama berupa hukum adat;

d. Mempunyai penguasa/pemimpin dan kelembagaan adat; dan

e. Mempunyai kekayaan, baik yang berwujud maupun yang tidak berwujud.

Menurut Sumardjono, ciri pokok masyarakat hukum adat yakni merupakan suatu kelompok manusia, mempunyai kekayaan tersendiri terlepas dari kekayaan perseorangan, mempunyai batas wilayah tertentu, dan mempunyai kewenangan tertentu. Sementara Saragih mengatakan, ada dua faktor pengikat anggota persekutuan hukum, yakni genealogis dan teritorial, yang selanjutnya menghasilkan tiga tipe pokok persekutuan. Tipe persekutuan tersebut dibagi kedalam, genealogis, teritorial, dan genealogis-teritorial.

Pada masyarakat genealogis terdapat dua macam persekutuan, yakni unilateral dan bilateral/parental, dan ditambah satu bentuk khusus, yakni alternerend (bergantiganti). Pada masyarakat unilateral, anggota-anggotanya berdasarkan garis keturunan satu pihak, yaitu pihak ayah atau pihak ibu. Jika garis keturunan dari pihak ibu, maka masyarakat tersebut adalah matrilinial, dan jika garis keturunan dari pihak ayah, maka masyarakat tersebut adalah masyarakat patrilinial. Selanjutnya, pada masyarakat 
bilateral, anggota-anggotanya menarik garis keturunan baik dari pihak ayah maupun dari pihak ibu, sedangkan pada masyarakat alternerend, anggota-anggotanya menarik garis keturunan berganti-ganti mengikuti bentuk perkawinan orang tuanya.

\section{Pengelolaan Lingkungan}

Lingkungan hidup manusia terdiri dari lingkungan alam, sosial dan lingkungan buatan yang mempunyai hubungan saling mempengaruhi. Lingkungan hidupa manusia terdiri atas lingkungan hidup sosial yang menentukan seberapa jauh lingkungan hidup alam mengalami perubahan drastis menjadi lingkungan hidup buatan.

Upaya meningkatkan pengelolaan lingkungan hidup dilakukan untuk mengadakan koreksi terhadap lingkungan dengan memodifikasi lingkungan, agar pengaruh merugikan dapat dijauhkan dan dilaksanakan pencegahan melalui efesiensi dan pengaturan lingkungan, sehingga bahaya lingkungan dapat dihindarkan dan keserasian serta keindahan dapat terpelihara. Soerjadi menyatakan ada tiga upaya yang harus dijalankan secara seimbang, yaitu teknologi, upaya tingkah laku atau sikap dan upaya untuk memahami/menerima koreksi alami yang terjadi karena dampak interaksi manusia dan lingkungannya. ${ }^{7}$

Chiras menyatakan bahwa lingkungan menunjukkan keluasan segala sesuatu meliputi air, binatang, dan mikro organisme yang mendiami tanah itu. jadi lingkungan termasuk segala komponen yang hidup dan tidak hidup, interaksi antar sesama komponen. Lingkungan hidup adalah sistem yang merupakan kesatuan ruang dengan semua benda, daya, keadaan dan makhluk hidup, termasuk di dalamnya manusia dan perilakunya yang mempengaruhi kelangsungan

${ }^{7}$ Muhammad Soerjadi. 1987. Lingkungan Sumber Daya Alam dan Kependudukan Dalam Pembanguan. UI Press. Bandung. Hlm. 78 
perikehidupan dan kesejahteraan manusia serta makhluk hidup lainnya. Perlu disadari bahwa ternyata pengelolaan lingkungan oleh manusia sampai saat ini tidak sesuai dengan etika lingkungan, yaitu manusia bersikap superior terhadap alam. Manusia beranggapan bahwa dirinya bukan bagian dari alam semesta sehingga dia boleh bebas mengelolanya bahkan dapat merusak lingkungan hidupnya.

Secara yuridis pengaturan tentang pengelolaan lingkungan hidup terdapat pada pasal 1 angka 12 UndangUndang nomor 32 tahun 2009 tentang Perlindungan dan Pengelolaan Lingkungan Hidup. Pasal ini menuliskan bahwa: "Upaya pengelolaan lingkungan hidup dan upaya pemantauan lingkungan hidup adalah pengelolaan dan pemantauan terhadap usaha dan/atau kegiatan yang tidak berdampak penting terhadap lingkungan hidup yang diperlukan bagi proses pengambilan keputusan tentang penyelenggaraan usaha dan/atau kegiatan."

Selanjutnya dijelaskan dalam Pasal 2, bahwa perlindungan dan pengelolaan lingkungan hidup dilaksanakan berdasarkan asas:

a. Tanggungjawab negara;

b. Kelestarian dan keberlanjutan;

c. Keserasian dan keseimbangan;

d. Keterpaduan;

e. Manfaat;

f. Kehati-hatian;

g. Keadilan;

h. Ekoregion;

i. Keanekaragaman hayati;

j. Pencemar membayar;

k. Partisipatif;

1. Kearifan lokal;

m. Tata kelola pemerintahan yang baik; dan

n. Otonomi daerah 
Sementara tujuan perlindungan dan pengelolaan lingkungan hidup diatur dalam pasal 3, yakni:

a. Melindungi wilayah Negara Kesatuan Republik Indoneisia dari pencemaran dan/atau kerusakan lingkungan hidup;

b. Menjamin keselamatan, kesehatan, dan kehidupan manusia;

c. Menjamin kelangsungan kehidupan makhluk hidup dan kelestarian ekosistem;

d. Menjaga kelestarian fungsi lingkungan hidup;

e. Mencapai keserasian, keselarasan, dan keseimbangan lingkungan hidup;

f. Menjamin terpenuhinya keadilan generasi masa kini dan generasi masa depan;

g. Menjamin pemenuhan dan perlindungan hak atas lingkungan hidup sebagai bagian dari hak asasi manusia;

h. Mengendalikan pemanfaatan sumber daya alam secara bijaksana;

i. Mewujudkan pembangunan berkelanjutan; dan

j. Mengantisipasi isu lingkungan global.

Upaya untuk meningkatkan kualitas lingkungan hidup atau untuk mendapatkan mutu lingkungan yang baik, dilakukan upaya memperbesar manfaat lingkungan dan memperkecil resiko lingkungan, agar pengaruh yang merugikan dapat dijauhkan sehingga kawasan lingkungan hidup tetap dapat terpelihara. Oleh karena itu setiap pengelolaan terhadap lingkungan hidup harus dilakukan secara sadar dan terencana. 


\section{Hukum Adat Masyarakat Petapahan dalam Pengelolaan Lingkungan}

Lingkungan hidup merupakan media hubungan timbal balik antara makhluk hidup dengan alam yang merupakan satu kesatuan yang utuh, dan manusia ada di dalamnya. Dikatakan manusia ada di dalamnya karena manusia adalah salah satu makhluk hidup yang sangat dominan peranannya dalam lingkungan hidup. Manusia dengan tingkah lakunya dapat mempengaruhi lingkungan (dapat mencemari, merusak atau melestarikan lingkungan) ${ }^{8}$

Bahaya yang senantiasa mengancam kelestarian lingkungan dari waktu ke waktu ialah pencemaran dan perusakan lingkungan, ${ }^{9}$ baik yang dilakukan akibat interaksi antara manusia dan lingkungan maupun terhadap lingkungan itu sendiri. Pencemaran dan perusakan lingkungan yang dilakukan oleh manusia berawal dari keinginan manusia dalam melakukan pembangunan. Pada hakikatnya pembangunan adalah gangguan terhadap keseimbangan lingkungan, yaitu usaha sadar manusia untuk mengubah keseimbangan lingkungan. ${ }^{10}$

Kehidupan masyarakat adat di Riau, terdapat konsepsi perubahan maupun perkembangan didalam hukum adat masyarakat setempat. Berawal dari Melayu-Polinesia berkembang di zaman hindu, kristen, dan kultur islam yang mempengaruhi corak maupun model dari hukum adat yang ditaati oleh masyarakat melayu pada saat itu. dapat kita lihat dengan banyaknya tradisi yang ada di dalam lingkungan

${ }^{8}$ Sodikin, Penegakan Hukum Lingkungan Tinjauan Atas UndangUndang Nomor 23 Tahun 1997, Penerbit Djambatan, Jakarta, 2007, hlm. 1.

9 Muhamad Erwin, Hukum Lingkungan Dalam Sistem Kebijaksanaan Pembangunan Lingkungan Hidup, PT. Refika Aditama, Bandung, 2008, hlm. 35.

10 Niniek Suparni, Pelestarian, Pengelolaan, dan Penegakan Hukum Lingkungan, Sinar Grafika, Jakarta, 1992, hlm. 36. 
sosial masyarakat berupa ungkapan, petatah/petitih maupun petuah. $^{11}$

Hukum adat memiliki sumber yang dibedakan atas sumber tertulis dan sumber tidak tertulis. Sumber hukum tidak tertulis terdiri atas adat-istiadat atau kebiasaan yang merupakan tradisi dari rakyat, kaidah kebudayaan tradisional, perasaan keadilan yang hidup didalam masyarakat, dan pepatah. Sedangkan sumber hukum tertulis terdiri atas dokumen-dokumen yang masih hidup, kitab hukum yang dikeluarkan raja-raja, doktrin tentang hukum adat, dan hasil penelitian. $^{12}$

Undang-Undang atau Kanun Melaka, Undang-Undang Lima Pasal Riau, Tarombo Siri di Rokan, Peraturan Kesultanan Indra Giri dan lain-lain ditemukan di Riau. Hal ini memperlihatkan adanya perkembangan yang terus terjadi pada masyarakat melayu yang memperlihatkan terus berkembangnya hukum adat ditengah masyarakat yang dipengaruhi oleh berbagai aspek. Dari suatu kebiasaan yang menjadi jiwa masyarakat sampai kepada aturan tertulis yang tidak menggeser nilai dan norma yang ditaati oleh masyarakat karena lahir atas kesepakatan serta kemauan dari masyarakat melayu itu sendiri. ${ }^{13}$

Terhadap aspek permasalahan lingkungan hidup, masyarakat adat melayu memiliki ciri khas atau karakter bagaimana mereka memperlakukan lingkungan. masyarakat adat Petapahan memiliki sistem atau aturan sendiri dalam mengelola dan melindungi lingkungan. Bentangan alam yang terdapat di kawasan masyarakat adat Petapahan terbagi menjadi dua, yaitu kawasan perairan (sungai) dan kawasan daratan. Terhadap kawasan tersebut memiliki sistem atau

11 Ulfiah Hasanah dkk, Hukum Adat Melayu Riau, Alaf Riau, Pekanbaru, 2011, hlm. 25

12 Ibid, hlm. 20.
13 Ibid, hlm. 26. 
aturan yang berbeda dalam pengelolaan dan perlindungan lingkungannya. Beberapa aturan adat masyarakat Petapahan dalam mengelola dan melindungi lingkungan, yakni:

\section{Pengelolaan dan Perlindungan Kawasan Perairan}

Masyarakat Petapahan hidup dan berkembang tidak terlepas dari kebermanfaatan sungai Tapung. Sebelum jalur darat di buka, satu-satunya akses bagi masyarakat adat Petapahan untuk bisa keluar dari kampung (desa) adalah dengan jalur perairan. Muhammad Nur, ${ }^{14}$ merupakan tokoh masyarakat Petapahan mengatakan bahwa sebelum kemerdekaan dan awal kemerdekaan Republik Indonesia, mata pencaharian masyarakat Petapahan didominasi dengan berdagang, nelayan dan berkebun. Dua dari tiga aktifitas ini menggunakan kawasan perairan, yaitu berdagang dan nelayan.

Terhadap aktifitas perdagangan, masyarakat membeli dan menjualkan barangnya di beberapa daerah, yaitu Senapelan (Pekanbaru), Siak Sri Indrapura hingga ke Malaysia. Pedagang-pedagang tersebut berlayar hingga berbulan-bulan dengan menggunakan kapal. Bagi mereka yang bernelayan, adalah selain hasil tangkapan ikannya untuk di makan oleh keluarga juga di jual di pasar. Sistem penangkapan ikan ini menggunakan pancing, jala, tombak, pukek (alat tangkap ikan tradisional khas Petapahan yang terbuat dari rotan) atau bahkan dengan menggunakan tuba.

Menurut Muhammad Nur, manubo (bahasa daerah dari kata menuba asal kata tuba) merupakan aktifitas menangkap ikan secara bersama-sama oleh masyarakat asli Petapahan. Manubo merupakan tradisi masyarakat Petapahan yang sudah turun temurun. Aktifitas manubo dilakukan dengan menggunakan racun yang berasal dari getah akar pohon karet.

${ }^{14}$ Wawancara dilakukan pada 15 Maret 2017 di Petapahan. 
Aktifitas menangkap ikan dengan menggunakan racun sudah dilarang oleh Negara, hal ini diatur dalam UndangUndang Nomor 45 Tahun 2009 tentang perubahan atas Undang-Undang Nomor 31 Tahun 2004 tentang Perikanan. Hanya saja aktifitas manubo yang dilakukan oleh masyarakat Petapahan adalah dengan menggunakan racun alami (getah akar pohon karet) bukan menggunakan zat-zat kimiawi yang dapat merusak lingkungan baik jangka pendek maupun jangka panjang.

Menurut pemerintah setempat kegiatan manubo ini merupakan aktifitas rutinan masyarakat Petapahan tiap air sungai sedang surut. Terhadap hasil pantauan yang dilakukan pemerintah, selama ini aktifitas manubo yang dilakukan oleh masyarakat Petapahan masih dalam batas wajar dan tidak menggunakan bahan beracun ataupun bahan berbahaya, sehingga tidak mencemar ataupun merusak lingkungan sungai Tapung.

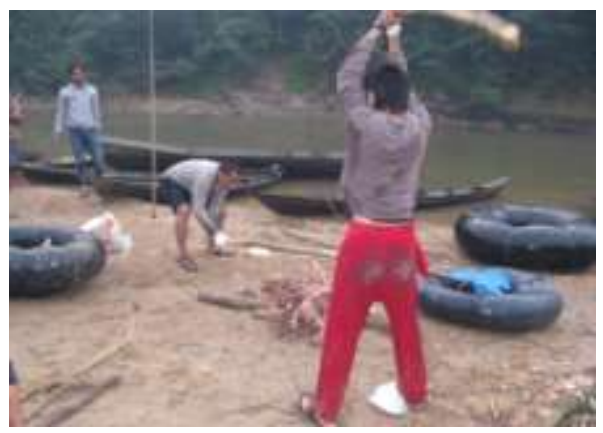

Gambar diatas merupakan aktifitas persiapan manubo, mereka mengumpulkan akar pohon karet dan memukulnya hingga getah tersebut keluar. Menurut salah seorang masyarakat Petapahan, Muslim Muhammad Said mengatakan bahwa akar ini akan dihanyutkan dari hulu ke hilir. Sehingga ikan-ikan yang berada disekitar akar tersebut akan mengalami pusing untuk beberapa saat. Terhadap ikan-ikan yang pusing ini akan mengapung keatas air sehingga gampang bagi masyarakat untuk mengambil ikan tanpa bantuan alat-alat tangkap ikan. Cukup mengambil ikan dengan tangan, hanya 
saja bagi ikan-ikan yang besar terkadang tetap membutuhkan alat tangkapan seperti tangguk. Karena menangkap ikan ini dilakukan secara bersama-sama, maka bagi mereka yang ingin mendapatkan ikan yang banyak harus menggunakan tangguk atau tombak, tetapi tidak diperbolehkan menggunakan jala. Larangan menggunakan jala ini dilakukan agar terpenuhi rasa keadilan untuk menikmati hasil perikanan yang ada di sungai Tapung.
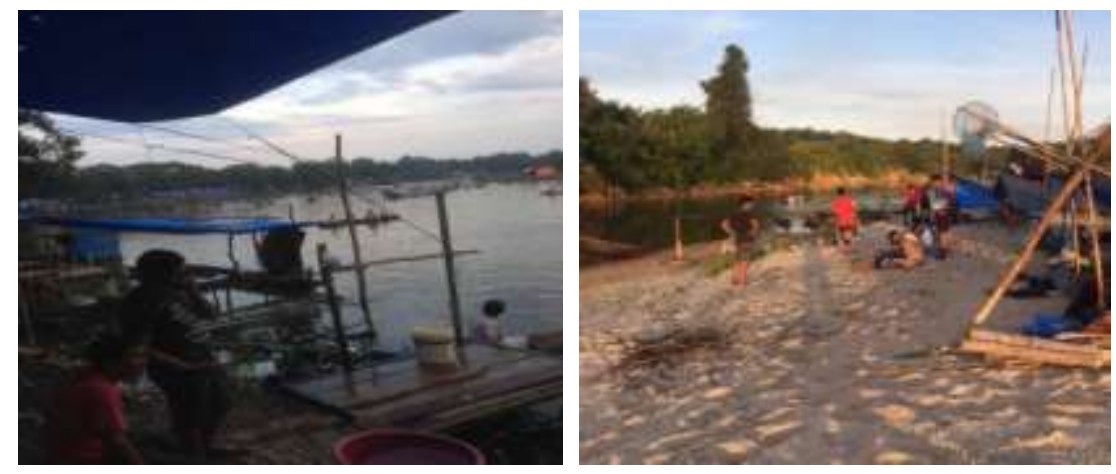

Gambar diatas memperlihatkan bahwa, masyarakat sedang menunggu tuba hanyut, yang nantinya akan membuat ikan pusing dan tergenang di atas sungai. Aktifitas manubo biasanya dilakukan mulai dari jam 02.00 shubuh hingga senja. Sore di hari persiapan, biasanya dilakukan untuk mengumpulkan getah pohon karet. Setelah itu, dini hari dilakukan untuk menghanyutkan akar tersebut. Sehingga pagi pukul 05.00 atau 06.00 ikan sudah banyak yang tergenang di permukaan air sungai.

Menurut Muhammad Nur, aktifitas adat manubo ini tidak dimaksudkan untuk merusak lingkungan perairan, justru bertujuan untuk memanfaatkan hasil sungai Tapung dengan baik agar terciptanya keseimbangan ataupun ikatan antara sungai dengan masyarakat Petapahan. Selama ini, aktifitas manubo hanya menggunakan getah pohon karet, tidak menggunakan zat-zat kimia yang dilarang oleh Pemerintah.

Terhadap aktifitas manubo yang menggunakan bahan alami, merupakan cara masyarakat Petapahan untuk tetap 
menjaga lingkungan kawasan perairan. Masyarakat Petapahan sudah mampu mengelola dan melindungi kawasan perairan dengan tidak mencederai alam sekitarnya jauh sebelum pemerintah membuat peraturan terhadap larangan menangkap ikan dengan menggunakan racun.

\section{Pengelolaan dan Perlindungan Kawasan Darat}

Pemetaan adat Kabupaten Kampar terhadap hutan tanah milik perkauman dan puak diatur oleh adat perpatih/datukdatuk, hutan ini disebut sebagai hutan ulayat. Hutan ulayat atau tanah ulayat merupakan suatu wilayah yang luas menurut kekuasaan kehidupan manusia secara turun temurun.

Masyarakat adat Melayu Kampar memiliki pembagian terhadap kawasan hutan ulayat/adat, antara lain: ${ }^{15}$

a. Pusaka tinggi;

b. Hutan soko, hutan tanak soko persukuan 4,5,7,9 besar, tanak soko yang dihibahkan untuk sosial, jalan, dan lain-lain

c. Hutan larangan

d. Hutan margasatwa

e. Hutan kepung sialang, yaitu hutan yang tidak boleh diganggu oleh siapapun

f. Hutan industri, yaitu hutan industri, suaka alam, produksi, hutan tetap, cadangan lainnya

Kabupaten Kampar telah menerbitkan Peraturan Daerah Nomor 12 Tahun 1999 tentang Hak Tanah Ulayat. Tata cara penggunaan tanah ulayat diatur pada pasal 5 ayat 1 , yaitu: "Kerapatan adat satu-satunya lembaga permusyawaratan tertinggi adat yang mengatur penggunaan dan/atau pemanfaatan serta pemindahan kepemilikan tanah ulayat." Pasal 6 ayat (1) mengatakan bahwa "Hak penguasaan tanah ulayat dibuat atas nama gelar Pemangku Adat yang berhak untuk itu sesuai dengan ketentuan adat." Pasal 7 juga

${ }^{15}$ Ulfiah Hasanah dkk, Op., Cit. 
mengatur larangan memindahkan kepemilikan tanah ulayat kecuali untuk kepentingan pembangunan di daerah, kehendak bersama seluruh warga masyarakat adat berdasarkan hukum adat yang berlaku.

Pengawasan terhadap penggunaan hutan ulayat dilakukan oleh masyarakat dan pemangku adat. Salah satu hutan turun temurun yang diwariskan oleh nenek moyang masyarakat adat Petapahan adalah hutan Imbo Putui atau dikenal dengan istilah Rimba Putus. Menurut Muhammad Nur, luas hutan tersebut diperkirakan sekitar 270 hektar. Selama ini masyarakat setempat sangat overprotectif dalam menjaga kelestarian lingkungan pada hutan ini. Tindakan tersebut dilakukan dengan membentuk kelompok tani dan berbagai organisasi atau lembaga-lembaga masyarakat yang aktifitasnya dilakukan dengan bertujuan terhadap penjagaan kelestarian hutan Imbo Putui.

Muslim Muhammad Said mengatakan, secara geografis hutan ini berbatasan dengan perkebunan sawit, menurut cerita orang tua-tua dahulu hutan imbo putuih digunakan sebagai tempat untuk orang-orang yang menuntut ilmu kebathinan (bertapa), sebelum ilmu kebtahinan (bertapa) selesai dikaji mereka tidak diperbolehkan keluar dari hutan imbo putuih.

Hutan imbo putuih juga digunakan sebagai rumah bagi flora dan fauna yang sudah hidup, tumbuh dan berkembang serta sudah membaur dengan masyarakat Petapahan. Terdapat harimau, beruang, dan tapir serta berbagai macam jenis burung yang masih berkembang di dalam hutan ini. Selain itu, tumbuh-tumbuhannya terdapat sekitar kurang lebih 60 (enam puluh) jenis pepohonan. Jenis-jenis pohon tersebut bervariasi, ada pohon kelat, pohon meranti merah, pohon kempas, pohon pasak bumi, pohon ara, dan lain-lain.

Pengelolaan dan perlindungan terhadap kawasan hutan Imbo Putuih dilakukan oleh masyarakat dengan melarang siapa saja yang melakukan aktifitas memburu dan menebang di hutan ini. Hutan ini termasuk sebagai kawasan hutan 
larangan. Terhadap hal ini, masyarakat Petapahan sudah membuat Peraturan Desa pada tahun 2014 yang melarang aktifitas memburu dan menebang di hutan Imbo Putui. Menurut Muhammad Nur, setiap pelanggaran yang dilakukan akan dikenai sanksi adat seperti apabila menebang pohon berukuran diameter $20 \mathrm{~cm}$ ke atas, akan diberi sanksi berupa pemberian semen sebanyak 50 (lima puluh) sak.

Ritual penebangan hutan hanya boleh dilakukan dengan meminta izin kepada pemerintah dan ninik mamak pada masyarakat Petapahan. Terhadap izin yang diberikan ini, menurut Muhammad Nur harus diberikan dengan alasan dan tujuan yang diperbolehkan oleh adat. Seperti dimanfaatkan untuk pembuatan jembatan di desa Petapahan, atau fasilitasfasilitas umum lainnya, selain itu juga untuk membangun rumah masyarakat yang kurang mampu ataupu membuat sampan untuk nelayan. Akan tetapi terhadap aktifitas ini tidak dilakukan dengan sembarangan, bagi mereka yang menebang diwajibkan untuk kembali menanam bibit pohon yang mereka tebang tersebut dengan jumlah yang sama.

Terhadap hukum adat yang lahir ditengah kehidupan masyarakat yang merupakan hasil kesepakatan masyarakat menjadi suatu aturan hukum yang cenderung mendapatkan apresiasi dari masyarakat tersebut. Masyarakat senantiasa patuh dan menghormati keberadaan aturan adat, sebagai sesuatu yang memiliki nilai dan menjadi ruh serta jiwa dalam kehidupan sehari-hari. Terkait persoalan lingkungan hidup, konstitusi menuliskan dalam Pasal $28 \mathrm{H}$ ayat (1), yaitu "Setiap orang berhak hidup sejahtera lahir dan bathin, bertempat tinggal, dan mendapatkan lingkungan hidup yang baik dan sehat serta berhak memperoleh pelayanan kesehatan."

Keberadaan hukum adat tidak terlepas dari pengakuan hukum adat sebagai sumber hukum positif di Indonesia. Sistem hukum di Indonesia yang mengadopsi dari sistem hukum Eropa Kontinental, Hukum Islam dan Hukum Adat 
memberikan asumsi kepada kita bahwa pengakuan terhadap aturan-aturan adat yang cenderung tidak tertulis tetap diakui eksistensinya hingga saat ini.

Hukum adat masyarakat Petapahan yang juga turut andil dalam mengelola dan melindungi lingkungan tentunya mendapatkan apresiasi yang penuh oleh Pemerintah setempat. Pada dasarnya dalam hukum adat tersebut terdapat kaidah atau nilai-nilai yang di adopsi dari kehidupan sosial dan cenderung bercorak magis-kosmis. Menurut alam fikir magiskosmis, manusia ditempatkan sebagai bagian yang tidak terpisahkan dari alam lingkungannya, manusia dipengaruhi dan mempengaruhi serta memiliki keterkaitan dan ketergantuangan dengan lingkungannya, sehingga wawasannya bersifat menyeluruh, holistik, dan komprehensif. Corak wawasan holistik membangun kesadaran bahwa kesinambungan hidup manusia sangat tergantung pada kelestarian fungsi dan keberlanjutan lingkungannya. ${ }^{16}$

\section{Kesimpulan}

Pengelolaan lingkungan yang dilakukan oleh masyarakat adat Petapahan berdasarkan hukum adat dilakukan untuk tetap menjaga keberadaan kawasan adat yang merupakan warisan dari para leluhur mereka. Berdasarkan kondisi geografis desa Petapahan, maka terhadap aktifitas pengelolaan lingkungan dapat dibedakan menjadi dua, yakni pengelolaan lingkungan kawasan perairan dan pengelolaan lingkungan kawasan daratan. Pengelolaan lingkungan kawasan perairan dilakukan dengan aktifitas ritual manubo, sementara pengelolaan lingkungan kawasan daratan dilakukan dengan menjaga keberadaan hutan Imbo Putuih. Saat ini, terhadap pengelolaan dan perlindungan hutan adat

16 Nyoman Nurjaya, Pengelolaan Sumber Daya Alam, Prestasi Pustaka Publisher, Jakarta, 2009, hlm. 177. 
Imbo Putuih sudah memiliki payung hukum, yakni dituangkan dalam Peraturan Desa yang dibuat pada tahun 2014. Regulasi ini mengatur tentang hak dan kewajiban masyarakat Petapahan terhadap pengelolaan dan perlindungan hutan adat Imbo Putuih. Selain itu juga mengatur tentang larangan-larangan yang tidak dibenarkan oleh masyarakat adat terhadap hutan adat Imbo Putuih.

\section{Daftar Pustaka}

Andasasmita, Komar, Notaris Selayang Pandang, Alumni, Bandung, 1983

Arsyad, Hasyim, Sejarah Bekas Kerajaan Petapahan, Pekanbaru, 1986

Erwin, Muhammad, Hukum Lingkungan Dalam Sistem Kebijaksanaan Pembangunan Lingkungan Hidup, PT. Refika Aditama, Bandung, 2008

Hasanah, Ulfiah dkk, Hukum Adat Melayu Riau, Alaf Riau, Pekanbaru, 2011

Nurjaya, Nyoman, Pengelolaan Sumber Daya Alam, Prestasi Pustaka Publisher, Jakarta, 2009

Santoso, Mas Achmad, Good Governance Hukum Lingkungan, Penerbit ICEL (Indonedian Center For Environmental Law), Jakarta: 2001

Setiadi, A.G. Kertasapoetra, Hukum Tanah, jaminan UndangUndang Pokok Agraria bagi Keberhasilan Pendayagunaan Tanah, Bina Aksara, Jakarta, 1985

Sodiki, Achmad, Politik Hukum Agraria, Konstitusi Pers, Jakarta, 2013

Sodikin, Penegakan Hukum Lingkungan Tinjauan Atas Undang-Undang Nomor 23 Tahun 1997, Penerbit Djambatan, Jakarta, 2007

Soekanto, Soejono, Pengantar Penelitian Hukum, Ui-Press, Jakarta, 2006 
26 Hengki Firmanda S: Hukum Adat Pengelolaan Lingkungan....

Soerjadi. Muhammad, Lingkungan Sumber Daya Alam dan Kependudukan Dalam Pembanguan. UI Press. Bandung, 1987

Suparni, Niniek, Pelestarian, Pengelolaan, dan Penegakan Hukum Lingkungan, Sinar Grafika, Jakarta, 1992 